\title{
Analysis of the Present Situation of Chinese Small Loan Company and
}

\section{Its Sustainable Development}

\author{
Chao Dijia ${ }^{1, a^{*}}$ and Su Weidong ${ }^{2, b}$ \\ ${ }^{1}$ School of Finance, Qilu University of Technology, Jinan, Shandong Province, China \\ ${ }^{2}$ School of Finance, Qilu University of Technology, Jinan, Shandong Province, China \\ 1935390282@qq.com, ${ }^{\mathrm{b}}$ claysu@163.com
}

\section{Key words: Small loan company; Development bottleneck; Sustainable development}

\begin{abstract}
In 2005, The People's Bank Of China decided to allow the establishment of small loan company and its policy that credit is included and deposit is excluded has attracted widespread attention since then. In the end of that year, the Rishenglong Small Loan Company was founded, which marked the new beginning of micro-credit. The emergence of small loan company has broken the monopoly of banking financial institutions, activated the rural financial market and provided customers who have different kinds of financial demands with differentiated products and services. In this paper, we analyze the present situation of Chinese small loan company and point out some problems it need to face in the process of their development. And in view of these problems, this paper puts forward constructive suggestions to ensure the sustainable development of small loan company in our country.
\end{abstract}

\section{Introduction}

Small loan company is a new financial model under the background of China's rapid economic development, which provides the low-income groups with continuous and unsecured micro-credit. As an important part of inclusive finance, small loan company plays an inestimable role in easing the issues of agriculture, rural development and rural residents and solving the SME's financing issue. Although there is a thriving scene in micro-credit industry, many problems still exist. As a single and immature model, small loan company needs to consider how to deal with numerous financial institutions' pursuit or interception and how to achieve sustainable development.

\section{Literature review}

There are only a few studies on micro-credit theory at home and abroad. Just as Mr.Mao Yushi says, micro-credit theory needs more researches about practical operations and the establishment and maintenance of related institutions are also required. Many Chinese scholars' researches are mainly about the risk control of small loan company and the suggestions on small loan company's development. Zhou Zhongming thinks that there are four chief micro-credit risks including lack of effective accountability, unsound restraint mechanism, insufficient safeguard mechanism of loan recovery and compensation mechanism of small loan company. He also puts forward measures to dissolve these risks such as dividing the level of loan demand, projecting market operation and relying on governmental financial subsidies. Zhang Xiaoqian considers that seeking funding from big banks is the only road for small loan company and its operation mode that credit is included and deposit is excluded cannot go on for a long time. Compared with the domestic theoretical research, foreign scholars pay more attention to exploring the practical operation of small loan company and their research is limited to the study of the definition or evaluation of small loan company. A British scholar called Martin says that the majority of small loan companies promise to 
reduce poverty but they are facing increasing pressures which result from the following aspects. First, they want to expand their coverage rate in the market but it doesn't mean that they can cover the area of poverty. Second, they need increase in order to realize the aim of the scale economy and financial self-sustaining. Last but not least, the amount of donors in the original capital is so finite that it is necessary for micro-credit to get the commercial capital.

With the deepening exploration of small loan company, the methods and theories in research will reach unanimity both in China and abroad. So risk control will focus on several points such as perfecting the laws of micro-credit, accelerating the reform of financial system and strengthening financial regulation.

\section{Present Situation and Development Bottleneck of Small Loan Company}

The number and scale of small loan company in China have increased rapidly since the SFC issued Guiding Opinions On The Pilot Of Small Credit Company. In the end of 2008 the number of small loan company is less than 500 while by the fourth quarter of 2013 its number is up to 7838 and total assets are 819.127 billion yuan. However, this record was broken again by the end of June 2015. The data shows that there are 8951 small loan companies, employing 114000 people, possessing 959.416 billion yuan.

Favorable macro-environment contributes a lot to the rapid development of small loan companies. First of all, the political environment supports the development. From Interim Provisions On The Administration Of Loan Companies to Small Loan Company Management Approach (Draft), the government has continually promoted the management and development of small loan companies, which making the whole industry more confident. Second, the thriving scene in small loan companies owes to the economic environment. With the deepening reformation in Chinese economic system, SMEs has become an important force in economic development. Besides, as an agricultural country, the issues of agriculture, rural development and rural residents have been big problems in the urbanization process. The emergence of these two problems helps promote and accelerate the process of the micro-credit industry, and some historical data really reflect that small loan companies have a big effect on solving financial problems of the two part.

Although the number of small loan company is still on the rise, the speed of its growth has slow down significantly from the second quarter of 2014. The unbalanced development of small loan company has been highlighted. Compared with mid-western areas in China, mid-eastern areas have advantages both in quantity and quality. According to the statistics of the People's Bank Of China, more than $15 \%$ of small loan companies are facing the loss situation. Some of them even have to get out of the market. Thus it can be seen that small loan companies are faced with development bottleneck and many disadvantages are gradually appearing.

(a) Lack of adequate and effective source of funds

The government indicates clearly that there are three parts making up small loan company's funds including original shareholders' capital contribution, donation and money from other financial institutions. It is not hard to see that there are some restricting factors in the three sources of funds. First of all, small loan company can only get a little support from the original shareholders' capital contribution due to the small scale of these small loan companies and their limited numbers of shareholders and capital. Second there are only a few charity organizations that are willing to donate and large institutions are seldom willing to donate a large funding. Finally it is about the commercial banks. The main capital source channel of small loan companies is commercial banks. But the loan interest rate is over the primary interest rate and even much higher than Shibor. Moreover, micro-credit company operates the loan business. However, if its own funds 
still need to be loaned, there's no doubt that the cost will increase. And if the small loan company suffers the problem of recovery, then it cannot pay back funds in time and will face bankruptcy.

(b) Powerful risk

Credit risk, interest rate risk and operational risk are three threats in our country's small loan company.

Small loan companies have no mechanism of guaranteeing the property, no technology of assessing the risk and no pre-loan investigation like commercial banks, so they will face more credit risks than other financial institutions. Small loan company needs to spend a long time recovering the loan because of adverse selection and information asymmetry. Though the People's Bank Of China has incorporated small loan companies into credit system, now most of them do not enter the system and information environment will aggravate the credit risk.

As to the loan interest rate in small loan companies, China Banking Regulatory Commission and the People's Bank of China stipulate that it cannot be lower than benchmark interest rate by 0.9 times and higher by 4 times. At present most of the small loan companies' loan interest rate maintains 2.5 times to 3 times of benchmark interest rate. So as long as the benchmark interest does not fluctuate frequently in short time, the possibility of interest rate risk they need to face is little. However, if the short-term macro-control is so frequent that it leads to distinct benchmark interest rate fluctuations, small loan companies are bound to suffer greater interest rate risk.

In the market, there are no professional training institutes and the number of practitioner staff cannot keep up with the growth. The following is the latest data in June 2015. The number of small loan companies is up to 8951, employing 114000 workers. However, on average each company just has 12.73 people. If the backstage staff and executives are excluded, the number of real clerks is less than the half of that. Talent competition will intensify this situation, and then the number of professionals can be counted on one's fingers. It is easier to lead to operation risk because the employees are lack of profound theoretical knowledge and professional skills.

(c) Lower profitability and heavier tax burden

It cannot form scale economy because of large precious investment and little self-funding scale. What's more, low financial leverage effect, low-lying return rate on equity and high capital cost will make small loan companies in a state of slight profit under the precondition of no risk capital. Small loan companies cannot enjoy the same preferential subsidies like other financial institutions and they also need to pay taxes whose standards are the same as those of common industrial and commercial enterprises which makes them undertake heavy tax burden. At present the small loan companies' sales tax is $5.6 \%$, the income tax is $25 \%$ while the general financial institutions' income tax is only $15 \%$.This low interest rate and high tax regulation seriously limit the development of small loan companies. If the cost of capital are excluded, the small loans company will be in a loss.

\section{Promoting the sustainable development of small loan company}

(a) Allowing asset securitization and making funds abundant

A common fault of China's small loan company is lack of strong capital and most of them have to rely on its own funds. Due to the self-funding restriction in number and scale there will be negative effects on its subsequent development. Except using shareholders' capital and turning retained earnings to capital, it can also be regarded as a good solution for small loan company to finance actively by making loans securitization.

In February 2013, the SFC issued The securities company asset securitization business management regulations (Draft) in which it provides that the fundamental asset of securitization is the property what can produce independent and predictable cash flow. Underlying asset can be a 
single property right or property and it can also be an asset portfolio with a number of property rights or property which are formed by property rights such as enterprise receivables, credit assets and trust beneficiary right, or formed by security including commercial paper shares, bonds and derivatives. According to this regulation, the credit assets of small loan company can be used as primary property in the way of selling to enter into the special asset management plan in securities company. So small loan company can receive money through transferring credit assets then the securities company distributes asset-backed securities in the support of repayment. If asset securitization can be obtained by national recognition then sources of funding problems can be solved.

(b) Risk management

The customers of small loan company are some individual business and SMEs, so we cannot ignore credit risk. With the development of the small loan company, perfecting the credit system becomes the urgent matter. They can take advantage of the public security department of personal identity system or personal information system database to select their superior customers. And entering credit reporting system of the People's Bank of China is not a bad choice. At the same time small loan company may not amplify the loan just for pursuing interests, expanding their scale and the excessive pursuit of market coverage. What they should do is to prudent lending mechanism from their actual situation.

To deal with the interest rate risk, small loan company should combine long-term products and short-term products. Moreover they must innovate ideals not only in the loan business. In Small loan company management approach (Draft), their business scope is adjusted to 'giving priority to loan business and part of the local and foreign business according to the regulatory approval'. So small loan company can conduct different service and products including equity investments, bond investment and income mortgage loans.

Continuous development of small loan company cannot be short of the talents. Improving the professional training scheme and attracting high level talents are the most two important points that small loan company needs to consider. First of all, in order to attract or retain the original high level management personnel, small loan company may introduce equity incentive and option incentive measures excepting improving the salary. What's more in order to manage the internal business personnel, it is necessary to carry out a series of skill training courses such as inviting experts to teach lessons about financial risk management or about related software operation.

(c) Changing into the community banks or rural banks

Interim Provisions on the establishment of village banks in small loan companies was issued in June 2009. And if small loan companies meet some requirements it points out then some reputable companies in them can be changed into rural banks. The rule effectively eases the tax and profit problems of small loan company and makes it possible to have the same business condition with the majority of commercial banks so that they can control the risk better and reap high profits. Taking both inside and outside measures can ensure its sustainable development. Government shall support the development of small loan companies actively and put into more preferential policies just like rural commercial banks or village banks. Just in this way can small loan companies go for long without worries.

\section{Conclusion}

In a word, small loan companies do well in maintaining the management of the SMEs and flourishing rural finance development. Of course in the micro-economic environment innovating small loan companies has both advantages and disadvantages. When they catch the opportunities 
they also face all kinds of challenges. Small loan company in China can own a broader development prospect only through constant innovation and when they focus on the scale advantage they also need to grasp product advantage.

\section{ACKNOWLEDGEMENT}

This work has been funded by Humanities and Social Science Foundation of Ministry of Education of China (12YJA630102) and National Statistical Research Project of China (2013307).

\section{References}

[1] Sun Jundong, Using asset securitization to solve the funds bottlenecks of small loan company, J. Finance and Accounting Monthly. 07 (2011) 47-49

[2] Cai Yangping, Analysis of the risk managements of Chinese small loan company, J. Economic Forum. 05 (2014) 71-73

[3] Cai Hanxu, The present situation of the development of China's small loan company and the research of the measures, J. Times Finance. 07 (2015) 32-34

[4] Liu Pingyi, Analyses of the present situation of Chinese small loan company, J. Enterprise Reform and Management. 16 (2015) 104-105

[5] Cai Yangping, Analysis of the risk managements of Chinese small loan company, J. Economic Forum. 05 (2014) 71-73

[6] Zhang Liyuan, The thinking of the sustainable development of Chinese small loan company, J. Inner Mongolia Science Technology \& Economy. 15 (2015) 44-45 